\title{
PUBLISHER CORRECTION OPEN Publisher Correction: Epigenetic silencing of Lgr 5 induces senescence of intestinal epithelial organoids during the process of aging
}

Ryoei Uchida ${ }^{1}$, Yoshimasa Saito ${ }^{1}$, Kazuki Nogami ${ }^{1}$, Yohei Kajiyama ${ }^{1}$, Yukana Suzuki ${ }^{1}$, Yasuhiro Kawase ${ }^{1}$, Toshiaki Nakaoka ${ }^{1}$, Toshihide Muramatsu', Masaki Kimura ${ }^{1}$ and Hidetsugu Saito ${ }^{1}$

npj Aging and Mechanisms of Disease (2019)5:5; https://doi.org/10.1038/s41514-019-0035-9

Correction to: $n p j$ Aging and Mechanisms of Disease https://doi. org/10.1038/s41514-018-0031-5, Published online 01 December 2018

The original version of this Article had an incorrect Article number of 1 , an incorrect Volume of 5 and an incorrect Publication year of 2019. These errors have now been corrected in the PDF and HTML versions of the Article.

Open Access This article is licensed under a Creative Commons Attribution 4.0 International License, which permits use, sharing, adaptation, distribution and reproduction in any medium or format, as long as you give appropriate credit to the original author(s) and the source, provide a link to the Creative Commons license, and indicate if changes were made. The images or other third party material in this article are included in the article's Creative Commons license, unless indicated otherwise in a credit line to the material. If material is not included in the article's Creative Commons license and your intended use is not permitted by statutory regulation or exceeds the permitted use, you will need to obtain permission directly from the copyright holder. To view a copy of this license, visit http://creativecommons. org/licenses/by/4.0/.

(c) The Author(s) 2019 